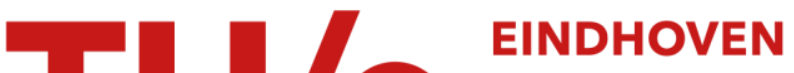

\section{Biomedical applications of additive manufacturing: present and future}

\section{Citation for published version (APA):}

Singh, S., Ramakrishna, S., Bouten, C. V. C. (Ed.), \& Narayan, R. (Ed.) (2017). Biomedical applications of additive manufacturing: present and future. Current Opinion in Biomedical Engineering, 2, 105-115.

https://doi.org/10.1016/j.cobme.2017.05.006

\section{Document license: \\ TAVERNE}

DOI:

10.1016/j.cobme.2017.05.006

Document status and date:

Published: 01/06/2017

\section{Document Version:}

Publisher's PDF, also known as Version of Record (includes final page, issue and volume numbers)

\section{Please check the document version of this publication:}

- A submitted manuscript is the version of the article upon submission and before peer-review. There can be important differences between the submitted version and the official published version of record. People interested in the research are advised to contact the author for the final version of the publication, or visit the $\mathrm{DOI}$ to the publisher's website.

- The final author version and the galley proof are versions of the publication after peer review.

- The final published version features the final layout of the paper including the volume, issue and page numbers.

Link to publication

\section{General rights}

Copyright and moral rights for the publications made accessible in the public portal are retained by the authors and/or other copyright owners and it is a condition of accessing publications that users recognise and abide by the legal requirements associated with these rights.

- Users may download and print one copy of any publication from the public portal for the purpose of private study or research.

- You may not further distribute the material or use it for any profit-making activity or commercial gain

- You may freely distribute the URL identifying the publication in the public portal.

If the publication is distributed under the terms of Article 25fa of the Dutch Copyright Act, indicated by the "Taverne" license above, please follow below link for the End User Agreement:

www.tue.nl/taverne

Take down policy

If you believe that this document breaches copyright please contact us at:

openaccess@tue.nl

providing details and we will investigate your claim. 


\section{Biomedical applications of additive manufacturing: Present and future Sunpreet Singh ${ }^{a}$ and Seeram Ramakrishna ${ }^{b}$}

\begin{abstract}
Three dimensional printing (3DP) or additive manufacturing (AM) of medical devices and scaffolds for tissue engineering, regenerative medicine, ex-vivo tissues and drug delivery is of intense interest in recent years. A few medical devices namely, ZipDose ${ }^{\circledR}$, Pharmacoprinting, powder bed fusion, HPAM $^{\mathrm{TM}}$, bio-printer and inkjet printer received FDA clearance while several biomedical applications are being developed. This paper reviews influence of type of AM method and process parameters on the surface topography, geometrical features, mechanical properties, biocompatibility, in vitro, and in vivo performance of diverse orthopedic applications. Attempts have been made to identify gaps, suggest ideas for future developments, and to emphasis the need of standardization.
\end{abstract}

\author{
Addresses \\ a Production Engineering, Guru Nanak Dev Engineering College, \\ Ludhiana, India \\ ${ }^{\mathrm{b}}$ Center for Nano Fibers and Nano Technology, National University of \\ Singapore, Singapore
}

Corresponding author: Singh, Sunpreet. (snprt.singh@gmail.com)

Current Opinion in Biomedical Engineering 2017, 2:105-115

This review comes from a themed issue on Additive Manufacturing Edited by Seeram Ramakrishna, Carlijn V. C. Bouten and Roger Narayan

Received 11 April 2017, revised 18 May 2017, accepted 29 May 2017

http://dx.doi.org/10.1016/j.cobme.2017.05.006

2468-4511/@ 2017 Elsevier Inc. All rights reserved.

\section{Keywords}

Additive manufacturing, Biomaterials, Characteristics, Orthopedic implants, Standards.

\section{Introduction}

ASTM-F42 Committee defined the additive manufacturing (AM) as a process of joining materials to make objects from 3D model data, usually layer on layer, opposite to conventional manufacturing technologies [1]. These technologies utilize an unconstrained environment, as highlighted in Figure 1.

AM researchers are developing a wide range of biocompatible feedstock material and processing systems for medical devices, like hip, knee or articular cartilage joints. The various biomaterials and their applications in biomedical engineering (refer Table 1). Table 2 summarized some of such applications.

The working principle, except the processing of feedstock, is same and the process (specifically in the task of implant development) starts from collection of the work starts with capturing the internal medical data of a patient through are the Computed Tomography (CT) and the Magnetic Resonance Imaging (MRI) technologies [7]. Then the collected images are converted into computer aided design (CAD) model via Digital Imaging and Communications in Medicine (DICOM) directory. The finalized CAD model should be simulated through MIMICS or 3D doctor software for visualizing the fitment [8]. A standardized procedure is available for generating the required Standard Triangulation Language (STL) format of implants [9]. After this, as per the requirements of the implant in-terms of desirable quality characteristics the input variables such as slice/layer thickness, printing speed, printing temperature, orientation, raster angle, air gap, contours, environmental temperature/conditions, type of input current, types of laser and its parameters, workhorse material, environmental factors, etc., can be selected on the basis of literature survey or personal experience. Figure 2 shows the schematic of converting human specific data into physical part via AM. The process starts from CT scan data and eventually completes after preliminary surgical verifications.

Issues such as: poor surface characteristics, poor dimensional accuracy, low strength, bio-compatibility, microstructure issues, corrosion of the implants, etc., need the research attentions. It is inevitable that some of the factors critical to the implementation of AM technologies are also important to the adoption of other manufacturing technologies [10]. Particularly, it is of big interest to study the effect of processing parameters on biocompatibility/cell culture analysis as the finally produced structure is liable to alter its properties as the processing conditions change, due to the variation in the material, geometry and integrity of the layers while fabrication task. No matter if the variations analyzed will be limited, but the improvements accomplished would always be supposed to have significations. Moreover, the standard test standards, often come into play while the test and analysis, may not be able to give realistic information because of its differentiation, from the customized orthopedic or tissue, in-terms of geometrical features. Hence, it is highly important to test and 


\section{Figure 1}

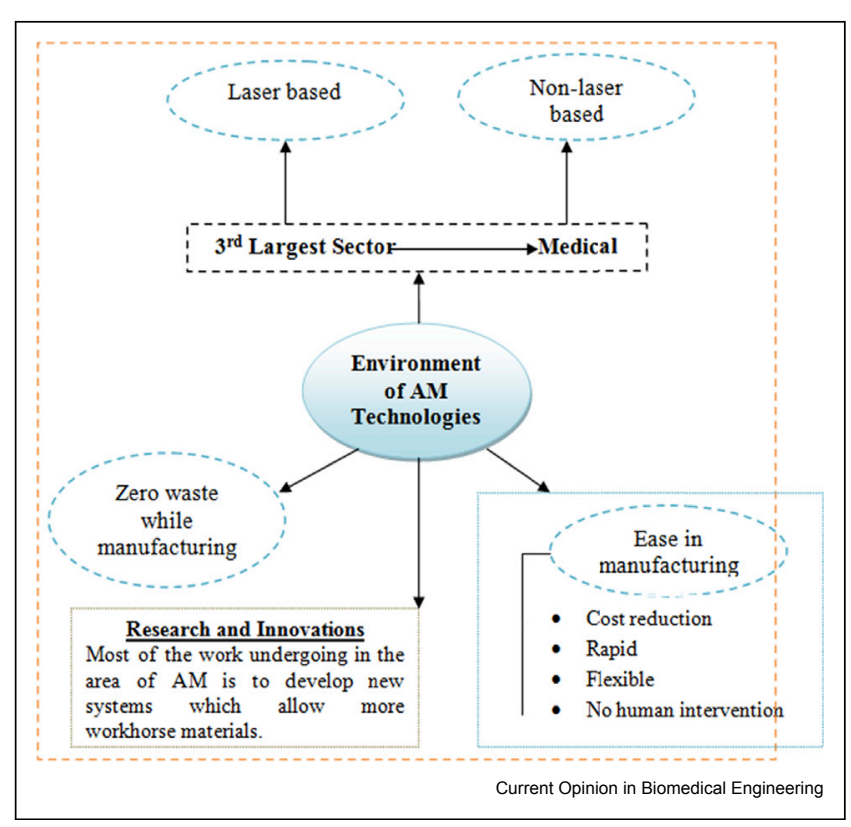

Environment of AM (Courtesy: ref. [1-6]).

simulate the laboratory results on the same part which is going to serve. Ducom Instrumentation has already developed apparatus for tribological testing of as-real geometry of the implants. In this review article, the influence of various process parameters on

\begin{tabular}{|c|c|}
\hline \multicolumn{2}{|c|}{ FDA cleared 3D printed biomedical applications. } \\
\hline Material & Application \\
\hline $\mathrm{CP}-\mathrm{Ti}$ & Screw and abutment \\
\hline Ti-6A1-4V & Artificial valve, Stent, Bone fixation \\
\hline Ti-6Al-7Nb & Crowns, Knee joint, Hip joint \\
\hline Ti-5Al-2.5Fe & Spinal implant \\
\hline Ti-15 Zr-4Nb-2Ta-0.2Pd & $\begin{array}{l}\text { Crown, Bridges, Dentures, } \\
\text { Implants }\end{array}$ \\
\hline Ti-29Nb-13Ta-4.6Zr & $\begin{array}{l}\text { Crown, Bridges, Dentures, } \\
\text { Implants }\end{array}$ \\
\hline $\begin{array}{l}83 \%-87 \% \mathrm{Ti}-13 \%-17 \% \mathrm{Zr} \\
\text { (Roxolid) }\end{array}$ & Crown, Bridges, Dentures \\
\hline $316 \mathrm{~L}$ & $\begin{array}{l}\text { Knee joint, Hip joint, Surgical tools, } \\
\text { Screw }\end{array}$ \\
\hline Co-Cr-Mo, Co-Ni-Cr-Mo & $\begin{array}{l}\text { Artificial valve, Plates, Bolts, } \\
\text { Crowns, Knee joint, Hip joint }\end{array}$ \\
\hline $\mathrm{NiTi}$ & Catheters, stents \\
\hline PMMA, PE, PEEK & $\begin{array}{l}\text { Dental bridges, articular cartilage, } \\
\text { Hip joint femoral surface, Knee } \\
\text { Joint bearing surface, Scaffolds }\end{array}$ \\
\hline $\mathrm{SiO}_{2} / \mathrm{CaO} / \mathrm{Na}_{2} \mathrm{O} / \mathrm{P}_{2} \mathrm{O}_{5}$ & $\begin{array}{l}\text { Bones, Dental implants, orthopedic } \\
\text { implants }\end{array}$ \\
\hline Zirconia & Porous implants, Dental implants \\
\hline $\mathrm{Al}_{2} \mathrm{O}_{3}$ & Dental implants \\
\hline $\mathrm{Ca}_{5}\left(\mathrm{PO}_{4}\right)_{3}(\mathrm{OH})$ & Implant coating material \\
\hline
\end{tabular}

Information gathered by online search. characteristics of orthopedic implant has been reviewed in Section 2, and the information provided will help for the development of required standards as discussed in Section 3.

\section{AM based biomedical implants: examples of manufacturing strategies for orthopedics}

In this section, we have reviewed the various characteristics of AM based orthopedic implants to highlight the importance of from process parametric study for obtaining better service life, safety, workability and convenience of patient after implantation. All the upcoming characteristics are important to get qualified during pre-surgical verifications after the fabrication of the implant, as highlighted in Figure 2.

\subsection{Surface characterization}

Implant surface characteristics plays an important role in the osteointegration like: macroscopic, microscopic and nano-metric characteristics [12]. It has been found that the reaction of osteogenic cells to different surfaces was increased on rough surfaces [13], and as compared to smooth surfaces the textured implants surfaces exhibit more surface area for integrating [14] as observed in in-vivo investigations [15]. However, fine surface finish has also been reported as better in case of hip joint applications [16], as fine contact between artificial implant and natural bone structure will help in smooth motion. However in actual, it is not yet standardized that how much rough or fine surface is required for different implants. The authors are believed that for non functional implants, one should prefer textured surfaces and such surfaces are easy to obtain with AM technologies due to the presence of staircase effect [17]. But when the implant is functional such that it has relative motion, then the mating surface should be as fine as possible as roughness could have effect on increased wear [18]. Some of the researchers have used chemical etching [19], mechanically [20] or combinations [21] for improving the surface finish of the titanium implants, however their effects on the chemical composition of the implant material, geometrical scale (to nano level) and other mechanical properties are required to study. Table 3 gives a detail of processing parameter(s) of AM process for surface roughness of produced implants.

\subsection{Geometrical characterization}

- Dimensional

Developments of exact shape, size and minute geometrical textures on artificial biomedical implants are essentially important for their proper functionality $[39,40]$. However, it is difficult to produce on an appropriate material and earlier was done by hand crafting from the surgeon [41]. Conventional CNC 
Table 2

3D Printed Biomedical Applications under research and development.

S. No. AM technology used

Application area

Biomaterial

Remarks

University/Lab/group

3D printing small implants

PEEK

2 Metal on Metal (MOM) Smart-hip

Custom design in orthopedics

Ti alloy

melting (EBM)

Selective laser

melting (SLM)

High-intensity sound for acoustic cleaning

Alginoplast

Customization of biocompatible implant

materials for AM

Multi applications of AM in biomedical

Polycaprolactone

Various types of polymers

High Performance Bioactive Structures for Silver ink

Bone Replacement and Tissue Growth

\section{Selective laser} sintering (SLS)

Processing of new materials by

Ti alloy

Biological mechanisms and optimization of $\mathrm{Ti}$ alloy tissue response by pore structure and surface modification

Medical imaging techniques

Theranostic Implants

Design and fabrication of biomimetic and $\mathrm{Ti}-\mathrm{Ta}$ biocompatible Ti-Ta for bone implants

Heterogeneous bio printing for in vitro drug toxicology testing
The project intends to develop and

extensive toolset for dental

implant design and analysis.

New PVD silver bearing coatings were University of Sheffield developed to

protect against post-operative infection

and provide a barrier to minimize metal ion

\section{release.}

Development of metal structures with

flexibility closer to the bone.

The sound pressure travels inside the

implant is a novel approach.

Craniofacial, long bone, ear and nose scaffolds are likely to develop.

Development of new 3D scaffolds able to Brightsland Material Centre

induce specific tissue regeneration

through engineered surface topology or

chemical surface functionality

Bone replacement and tissue growth for Loughborough University

individuals who have suffered the loss of

these structures through congenital

defects, trauma or destructive surgery.

Phenomenon of processing of polymer

nano-composites, thermoplastic

elastomers, biomaterials, polyethylene will

be understood.

To probe the structural arrangement,

molecular composition and morphology of the bone in-growth in different implant

geometries and surface morphologies.

Techniques using micro-CT imaging to

measure and map deviations due to wear

in implants are being developed.

To develop active implants that combine

therapeutic and diagnostic functions in a

single medical device.

To combine structural and materials

RMIT University

engineering, additive manufacturing and

tissue engineering to develop biomimetic

bone-like scaffolds.
Mid Sweden University

University of Liverpool

EOS and University of Michigan

University of Nottingham

Biomatcell; University of Gothenburg; SP Technical Research Institute of Sweden; Region Västra Götaland; Uppsala

University; Arcam AB

Lawson Health Research Institute

Frounhofer, German

Drexel University 
15 Fused deposition modelling (FDM) (SLA)

Bio printer

Bio printer

Inkjet printer

-

Inkjet printing

$$
-
$$

28

29
Hydrogel-based materials for implants

Heart Implants, 3-D-Printed to Order

3D print biodegradable vascular stents

Retinal Implant

Liver printing

Bone and cartilage

Heart chip

Cartilage

Kidney tissues

Scaffolds
Novel dosage forms

Morphogenetic protein 2, rhBMP-2
A locking mechanism for precise actuation Columbia University

and movement of freely moving hydrogel

was developed.

This research is a real step forward as it Nottingham Trent University

shows how we can use 3D printing to

improve biomaterials without the need for

achieving high resolution.

A stretchy, FDA-approved Tailor-made medical devices could give a MIT University polymer

more detailed picture of cardiac health and

may be better at predicting and preventing

problems.

In house polymer with antioxidant and retinoid properties

Micro continuous liquid interface

production to create stents for the

treatment of weakened or narrowed

arteries.

The developed material is FDA approved. Restoring Vision Platforms

3D printing for liver tissue engineering Northwestern University

Printed a bionic ear by combining University of Cambridge

biological tissue and electronics

Regeneration and analysis of

University of Cambridge

Stem cells

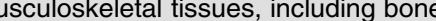

and cartilage.

Bioprinting for tissue and organ fabrication Penn State University

Poly-di-methyl-siloxane

polymeric bioinks with

tailored composition

Protein and enzyme

3-D printer builds heart-on-a-chip device

3D Bioprinting

Harvard University

3D Printed Human Skin Tissue

Biosurface engineering through ink jet

IIT, Delhi

trithiocarbonate iniferters

printing

Transformation of Parent Gels into

Lréal USA \& Organovo Team

USA federal science

Diversely Functionalized Daughter Gels

Made Possible by Visible Light

Photoredox Catalysis

3D Printing of solid and semi-solid dosage University of Central Lancashire

forms

3D-printed bioabsorbable scaffold for ACL The Mayo Clinic, USA reconstruction

Information gathered by online search 


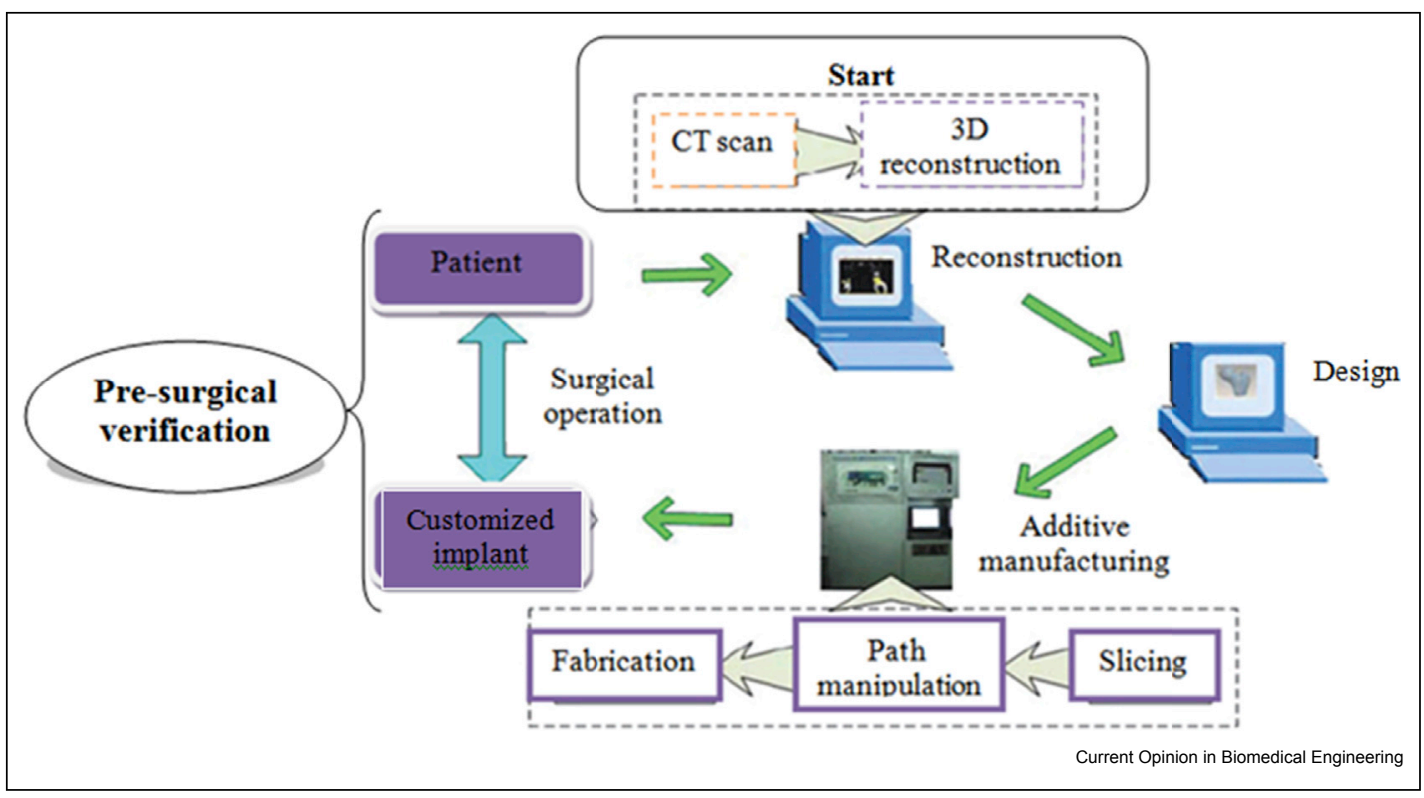

Schematic of AM of customized biomedical part [11].

machining has also been widely practiced to create human femur models but dimensional accuracy of the finished product was subjective of machining orientations [42]. Other processes such as: chemical etching, grit blasting, dies sinking electric discharge machining and ultrasonic machining were also used to produce fine and accurate surface textures [43]. One of the research article highlighted that the dimensional accuracy of the printed implants measured by $3 \mathrm{D}$ laser scanning, showed an average of $200 \mu \mathrm{m}$, which allows its application in craniofacial structures [44]. Another research article detailed that the scanning and processing pipeline creates a very-high dimension parameter space for which it would be prohibitive from a time perspective to fully investigated [45]. Although the above review of literature is highly supporting that the implants fabricated through AM are highly dimensional stable and are came up with near net features. Further, it has been quoted that the dimensions deviation of $200 \mu \mathrm{m}$ is suitable for some implants only, not for all. So, the research outcomes are lacking to give a clear picture of parameters affecting the dimensional accuracy.

\section{- Pore consistency}

Porous surface having an interconnected pores are recommended for the improvement of bone formation rate and also for the better fixation of the implant [46]. Implant porosity promotes positive results in bone neoformation in-vivo [47], as increased contact area between the biomaterials and bone tissue, result into better implant stability as well as accelerated osteointegration [48]. AM allows full design freedom, in a way by giving the possibility to manufacture regular open porous structures along with high repeatability which enhance both geometrical and mechanical properties [49]. In one of the study on SLM [49], it has been found from biomechanical testing that porous multi rooted implants had a much higher bonding strength at the bone-implant interface than the resorbable blasting media implant. The porosity can be designed in areas based on the patient's need to enhance biological fixation and achieve long-term in-vivo stability [50]. Overall, it has been summarized that there are various machine parameters that affected the pore size and its control overall the geometrical surface and the selection of their levels must need pilot study.

\subsection{Mechanical characterization}

Human joints or limbs posses certain desirable mechanical properties for ease of functionality as longer as the life. It has been found that the Young modulus, tensile strength, compressive strength and toughness of the human bone are a function of age, gender, and location in the body, amount of water and disease history [51]. Table 4 gives the illustration of mechanical properties of various joints developed through AM technologies. It has been found that the mechanical properties of parts produced with AM technology are competitive to cast material and the ultimate tensile strength variation was a function of orientation and location of the specimens [52]. Some of such comparisons of mechanical properties between cast/ wrought and AM sample are given in Table 5. However, 
Table 3

Effect of processing parameters on orthopedic implant characteristics.

\begin{tabular}{lllll}
\hline S. No. & AM system used & Parameters studied & Remarks & Reference(s) \\
\hline
\end{tabular}

\section{Surface roughness}

$1 \quad$ Selective laser sintering

Build orientation, layer thickness and laser power

2 Selective laser melting Build orientation

3 Electron beam melting Fused deposition modelling Selective laser sintering Fused deposition modelling Geometry of the components/appliance, density of components/ appliance and acetone exposure time

Current, scan speed and thickness of sample

Volume to area ratio, orientation and density of the parts

Fused deposition modelling

yer thickness, orientation, raster angle, raster width and air gap

$8 \quad$ Selective laser melting Laser power and scan speed

\section{Laser power}

Dimensional accuracy

$1 \quad$ Fused deposition modelling

Layer thickness, orientation, raster angle, raster width and air gap

Fused deposition modelling

Different geometries

3

Stereo-lithography

4

Selective laser sintering

Electron beam melting

Inkjet printing
Hatch spacing, layer thickness, overcure, blade gap and position on the build plane Laser power, hatch spacing, scan speed, bed temperature and scan length Orientation

Layer thickness and printing orientation
- Build orientation was found to be the dominant parameter affecting surface roughness.

- When layer thickness is small, better finish is obtained as compared to higher layer thickness.

- Penetration of laser of the same order of energy density may cause over-sintering and hence deteriorate surface finish.

- As the inclination angle increases from $0^{\circ}$, higher surface roughness results from the stair step effect.

- The trend of measured roughness is mainly constant in the range of $5^{\circ}-45^{\circ}$, with a relatively slow decrease in the range $50^{\circ}-90^{\circ}$.

The surface roughness increases with increasing sample thickness and beam current, while it decreases with increase in offset focus and scan speed.

Increasing the scan speed resulted into deteriorating the surface topography of the produced parts.

The results of ANOVA highlighted that only part density has contributed significantly $(90.29 \%$ at $95 \%$ confidence level) to the hardness of HVS-processed FDM parts.

- The orientation at 0 angles produces the minimum surface roughness and the value of surface roughness increases as the orientation changes from 0 to 90 .

- Patterns with lesser density produce less surface roughness as compared to solid patterns.

Raster angle and air gap have a positive influence on flexural strength.

- Higher peak powers tended to reduce top surface roughness and reduce side roughness as recoil pressures flatten out the melt pool and reduce balling formation by increasing wetability of the melt.

- Reduced scan speed reduced top surface roughness but increased side roughness.

- High laser power increased the surface finish.

- For minimizing the percentage change in length, higher layer thickness $(0.254 \mathrm{~mm}), 0^{\circ}$ orientation, maximum raster angle (60), medium raster width $(0.4564 \mathrm{~mm})$ and maximum air gap $(0.008 \mathrm{~mm})$ are desirable.

- FDM machine is less accurate in fabricating the circular shape such as a sphere, cylinder and hole as its dimension have exceeded the tolerance value $( \pm 0.127 \mathrm{~mm})$ of FDM machine.

- Overcure and build plane have high effect on the dimensional accuracy of the parts.

The shrinkage along $\mathrm{X}, \mathrm{Y}$ and $\mathrm{Z}$ direction is not independent

- The degree of inaccuracy can be mitigated significantly when the beam energy density is suitably reduced $-41.2 \%$ to $-5.4 \%$.

- The $0.1125 \mathrm{~mm}$ layer thickness and $X$ direction were the best printing conditions that offered the highest green strength and dimensional accuracy 
Table 3 (continued)

\begin{tabular}{|c|c|c|c|c|}
\hline S. No. & AM system used & Parameters studied & Remarks & Reference(s) \\
\hline 7 & Direct metal laser sintering & $\begin{array}{l}\text { Laser power, scan } \\
\text { speed, hatch space and } \\
\text { thickness }\end{array}$ & $\begin{array}{l}\text { - With increasing the laser power or decreasing the scan } \\
\text { speed, the shrinkage along the sintering (length) direction of } \\
\text { the part is more serious. } \\
\text { - Increasing the scan speed reduced the dimensional error. }\end{array}$ & {$[37]$} \\
\hline 8 & Direct metal laser sintering & $\begin{array}{l}\text { Length of the part and } \\
\text { scan speed }\end{array}$ & $\begin{array}{l}\text { - The length of the dexel is shorter; the percentage shrinkage is } \\
\text { larger because of a higher sintering temperature attained. } \\
\text { - When the length of the part was shorter, the shrinkage was } \\
\text { higher. }\end{array}$ & [38] \\
\hline
\end{tabular}

Table 4

\begin{tabular}{|c|c|c|c|c|c|c|c|c|c|}
\hline Implant & AM technology & Material & TS & YM & $S$ & $\mathrm{H}$ & CS & $\mathrm{FL}$ & Ref. \\
\hline PS & EBM & Ti6Al4V & - & - & $\begin{array}{l}0.57-2.92 \\
\mathrm{GPa}\end{array}$ & - & $\begin{array}{l}7.28-163.02 \\
\mathrm{MPa}\end{array}$ & - & [58] \\
\hline PS & - & Ti6AL4V-ELI & - & $>3.5 \mathrm{GPa}$ & $2.9 \mathrm{GPa}$ & - & - & - & [59] \\
\hline $\begin{array}{l}\text { Total } \\
\text { knee joint }\end{array}$ & EBM & Ti-6Al-4V & - & - & $\begin{array}{l}2.2 \mathrm{GPa} \text { outer } \\
\text { and } 0.3 \\
\text { GPa inner }\end{array}$ & $\begin{array}{l}3.9 \mathrm{GPa} \\
(\max .)\end{array}$ & - & - & [60] \\
\hline Ortho & SLM & $\begin{array}{l}\text { AISI-Stainless } \\
\text { steel }\end{array}$ & $738 \mathrm{MPa}$ (max.) & - & - & $250 \mathrm{HV}$ & - & - & [57] \\
\hline Ortho & - do- & Ti-6Al-4V & $>150 \mathrm{MPa}$ & & $>4 \mathrm{GPa}$ & - & - & - & [61] \\
\hline PS & Lithography & 45S5 Bioglass $®$ & $40 \mathrm{MPa}$ & - & - & - & $0.33 \mathrm{MPa}$ & - & [62] \\
\hline $\begin{array}{l}\text { Dental } \\
\text { implants }\end{array}$ & $\begin{array}{l}\text { EBM and } \\
\text { LBM }\end{array}$ & Ti-6AI-4V ELI & - & - & - & - & - & 28961SD & [63] \\
\hline Ortho & EBM & Ti-6Al-4V & $\begin{array}{l}833 \mathrm{MPa} \\
\text { (horizontal) and } \\
851 \mathrm{MPa} \text { (vertical) }\end{array}$ & $\begin{array}{l}783 \mathrm{MPa} \\
\text { (horizontal) and } \\
812 \mathrm{MPa} \text { (vertical) }\end{array}$ & - & - & - & - & [54] \\
\hline- & EBM & Ti-6Al-4V & $915 \mathrm{MPa}$ & $118 \mathrm{GPa}$ & - & - & - & - & [64] \\
\hline- & $\begin{array}{l}\text { Powder } \\
\text { based AM }\end{array}$ & $\mathrm{CP}-\mathrm{Ti}$ & $414.51 \mathrm{MPa}$ & $3.37 \mathrm{GPa}$ & - & - & $>400 \mathrm{MPa}$ & - & [55] \\
\hline Ortho & EBM & $\begin{array}{l}\text { Ti-6Al-4V and } \\
\text { Co-29Cr-6Mo } \\
\text { alloy }\end{array}$ & - & $\begin{array}{l}1.03-110 \mathrm{GPa} \text { and } \\
0.51-0.77 \mathrm{GPa} \text { res. }\end{array}$ & - & $\begin{array}{l}3.6-4.1 \mathrm{HV} \\
\text { and } 4.6 \mathrm{HV} \\
\text { res. }\end{array}$ & - & - & [65] \\
\hline
\end{tabular}

Note: TS, YM, S, H, CS, FL and PS represent tensile strength, Young's modulus, shear strength, hardness, compressive strength, fatigue life and porous structure.

the tensile elongation values in laser-based AM components, previously reported, lies to be typically $6 \%$ and maximum of $11 \%$, which are substantially lower than the $12-17 \%$ elongation range observed in wrought conditions [53]. In a study on EBM [54], the effect of post processing operations such as: machining and peening on residual stress, static strength and elongation, fracture toughness, crack growth and on fatigue performance were evaluated. Different orientations and numbers of channels [55], and energy input per unit length [56] affected the characteristics of implants. The optimization of process parameters through design of experiments has the scope to functionally improve the medical implants or instruments [57].

\subsection{Biological characterization}

- In-vitro

The in-vitro characterization of the artificial implants or medical instruments is the only essential process to be analyzed prior to their use. Study outcomes of in-vitro developments are crucial that provide important for proof of concept and in determination that whether a process/material is suitable for producing biocompatible structures or not. The rough structure of implant has positive influence on cell behavior as reported in numerous studies [70]. Recent innovations in AM technologies, such as bio-printers, have given a breakthrough in medical engineering as they allow 3D cellprinted devices [71]. Numerous histomorphometric studies highlighting the applications of AM for animal [72] and human [73] have documented. Pore size and its structure have significant effect on the cell culture results [71]. It has been found that the various geometrical parameters define the in-vitro results however optimum geometrical features are not defined till date.

- In-vivo

The materials/technologies/structures after getting qualified in in-vitro analysis are proceeding towards in- 


\begin{tabular}{|c|c|c|c|c|c|c|c|c|}
\hline \multicolumn{9}{|c|}{ Comparative mechanical properties of cast/wrought and AM parts. } \\
\hline \multirow[t]{2}{*}{ Material } & \multirow[t]{2}{*}{ AM setup } & \multicolumn{3}{|c|}{ Cast/wrought component } & \multicolumn{3}{|c|}{ 'Additive manufacturing } & \multirow[t]{2}{*}{ Reference } \\
\hline & & TS (MPa) & Elongation (\%) & Yield strength (MPa) & TS (MPa) & Elongation (\%) & Yield strength (MPa) & \\
\hline Inconel 718 & SLM & $<1000$ & $23 \%$ & - & 1400 & $>18 \%$ & - & [66] \\
\hline Ti-6Al-4V & -do- & 897 & $15 \%$ & 828 & 1095 & $8.1 \%$ & 890 & {$[67]$} \\
\hline 316L stainless steel & -do- & 560 & $40 \%$ & $<290$ & 555 & $13.5 \%$ & 465 & {$[68]$} \\
\hline Ti-6Al-4V & DMLS & 979 & - & 945 & 1133 & - & 1096 & [69] \\
\hline SS-316L & -do- & 563 & - & 343 & 717 & - & 496 & [69] \\
\hline
\end{tabular}

vivo studies, where the selected implant is planted inside an animal (cat, rat, rabbit, sheep, etc.) [74]; or even directly in human body. The porous Ti6Al4V scaffold prepared by EBM was favorable for bone ingrowth after implanted in sheep femoral [75]. In Ref. [76], the effect of porous structures on their biological behavior has been outlined. The effect of AM structures pore size on the in-vivo results is analyzed. Overall, it has been observed that the control of porosity through AM technologies is important.

\section{- Corrosion}

Usually, corrosion may appear during the conventional adaption of implants due to the fact that plastic deformation and may break the passive layer of the contact area [77]. AM is capable of producing good corrosion resistance and compatibility [78]. Surface roughness and porosity may affect the corrosion of AM based implants [79]. Potentiodynamic tests for Ti-6Al-4V alloy showed that both EBM and wrought alloy similar corrosion resistance [79]. Heat treatment of the AM manufactured implants is one of the convincing approaches to improve their corrosion resistance.

\section{Applicable standards in AM of implants}

From Section 3, it has been observed that the research strategies are diverse and hence the results obtained are variable, even conflicting in most of the cases. Hence the time is demanding systematic approaches for the development of particular type of biomedical structure as it is not convenient for the surgery team to carry out pilot studies prior to the operations. Here, standards play an important role in the adoption of a suitable technology. For this significant activities have been taken place, since 2009, through the ASTM International F42 committee which critically worked towards standards in materials and processes, terminology, design and data formats and test methods. Especially in medical sector the growth of the AM industry is slow due to the unavailability of specified standard procedures and human expertise dominates their existence. Due to this the expert usually explore only into those aspects in which they are comfortable rather than a state of the art implant behavior. ASTM F2792-12a, ISO/
ASTM DIS 52910.2, ISO/TC 261 and ISO 17296-4:2014 standards are available for the starters. Also, ISO 109931 and ASTM F 2129 standards are available for chemical characterization, and ASTM 756 and ISO 10993-6 standards help in testing biocompatibility of the implants. Still researchers need a full proof procedure (from first to last stage) which demands following standards to be available in near future:

- Conversion of DICOM files into 3D model; its procedure, how to control surface and geometrical feature at earlier stage, critical points to be taken care of; suitable rendering technology.

- Preparation of STL file; how to adopt the best slicing strategy; how to eliminate the errors occurred, often.

- Selection of suitable AM technology; since the availability of AM systems is wide so proper selection of AM setup is most important. Through the establishment of standards, one can compare the performance of different AM processes and find out the best.

- Selection of AM parameters; from literature it has been clarified that processing parameters of the machine are highly contributing towards the output characteristics of the implants. However till now it has not been standardized that for what category of implants which processing parameters are best suitable.

- Characterization and testing; As most of the mechani$\mathrm{cal} /$ tribological studies on implants are performed on standard specimens prepared as per ASTM/ISO/ ANSI. However, no standard is yet available for testing implants. Here, in regular practices researchers violate the geometrical aspects of the implants that contribute towards certain mechanical properties.

\section{Conclusions}

Followings are the brief conclusions drawn from the literature review:

- It has been found that AM technologies are promising for converting the customized implants through available scanning technologies like CT/MRI. Till date extensive research work has been carried out for improving the various quality characteristic of $\mathrm{AM}$ implants, and reportedly these characteristics are 
function of process parameters. Especially, importance should be given to the load bearing implants to achieve mechanical and fatigue performance together.

- The certification of AM critical components has been a critical challenge due to the availability of the conflicting process parameters due to which there exist significant gaps in the selection of their levels. Overall the suggested optimized process parameters are still not at par with the mechanical standard as a result of which the developed components are not immediately ready to use and their post treatment is frequently required.

- Very less work has been done, till date, to simulate the cell responses and cell-tissue growth behavior as a function of process variables.

- There is a myriad of variations for medical devices, in general. This is a benefit, but requires standardization. But, researches focused on the development of norms and standard procedures for such practices are lacking. Moreover we need to seek product opportunities for fabricating regular products (like: screws, plates, etc.) for mass manufacturing point of view.

\section{Conflict of interest}

None.

\section{References}

Papers of particular interest, published within the period of review, have been highlighted as:

- of special interest

$\bullet$ of outstanding interest

1. ASTM. ASTM F2792-10 standard terminology for additive

- manufacturing technologies.

2. Horn TJ, Harrysson OL: Overview of current additive manufacturing technologies and selected applications. Sci Prog 2012 Sep 1, 95(3):255-282.

3. Guo N, Leu MC: Additive manufacturing: technology, applications and research needs. Front Mech Eng 2013 Sep 1, 8(3) 215-243.

4. Campbell I, Bourell D, Gibson I: Additive manufacturing: rapid prototyping comes of age. Rapid Prototyp J 2012 Jun 8, 18(4) 255-258.

5. Lu B, Li D, Tian X: Development trends in additive manufacturing and 3D printing. Engineering 2015 Mar 31, 1(1) 085-089.

6. Wohlers TT: Wohlers report: additive manufacturing and $3 d$ printing state of the industry. Annu Worldwide Progress Rep2013.

7. Yandell K: Organs on demand. Science 2013 Sep 1, 27:38-45

8. Cheah CM, Chua CK, Tan $\mathrm{KH}$, Teo CK: Integration of laser surface digitizing with CAD/CAM techniques for developing facial prostheses. Part 1: design and fabrication of prosthesis replicas. Int J Prosthodont 2003 Jul 1, 16(4).

9. Sun W, Starly B, Nam J, Darling A: Bio-CAD modeling and its applications in computer-aided tissue engineering. Comput Aided Des 2005 Sep 15, 37(11):1097-1114.

10. Mellor S, Hao L, Zhang D: Additive manufacturing: a framework

- for implementation. Int J Prod Econ 2014 Mar 31, 149:194-201.

11. Su XB, Yang YQ, Peng YU, Sun JF: Development of porous medical implant scaffolds via laser additive manufacturing Trans Nonferrous Metals Soc China 2012 Oct 1, 22:s181-s187.
12. Le Guéhennec L, Soueidan A, Layrolle P, Amouriq Y: Surface - treatments of titanium dental implants for rapid osseointegration. Dent Mater 2007, 23:844-854.

13. Albrektsson T, Wennerberg A: Oral implant surfaces: part

- review focusing on topographic and chemical properties of different surfaces and in vivo responses to them. Int $J$ Prosthodont 2004, 17:536-543.

14. Albrektsson $\mathrm{T}$, Berglundh $\mathrm{T}$, Lindhe $\mathrm{J}$ : Osseointegration: his-

- $\quad$ toric background and current concepts. In Clinical periodontology and implant dentistry. 4th ed. Oxford: Blackwell Munksgaard; 2003:809-820.

15. Gotfredsen K, Wennerberg A, Johansson CB, Skovgaard LT,

- Hjørting-Hansen E: Anchorage of TiO2-blasted, HA-coated and machined implants. An experimental study in rabbits. $J$ Biomed Mater Res 1995, 29:1223-1231.

16. Singh $R$, Singh $S$, Kapoor $P$ : Investigating the surface roughness of implant prepared by combining fused deposition modeling and investment casting. J Process Mech Eng 2016. http://dx.doi.org/10.1177/0954408914557374.

17. Sreedhar P, Mathikumar MC, Jothi G: Experimental investigation of surface roughness for fused deposition modeled part with different angular orientation. Adv Des Manuf Technol J 2012, 5:21-28.

18. Kim YH, Ritchie A, Hardaker C: Surface roughness of ceramic femoral heads after in vivo transfer of metal: correlation to polyethylene wear. J Bone Jt Surg 2005, 87(3):577-582.

19. Gustavo Mendonça, Mendonça Daniela BS, Aragão Francisco JL, Cooper Lyndon F: Advancing dental implant surface technology - from micron- to nanotopography. Rev Biomaterials 2008, 29:3822-3835.

20. Longhitano GA, Larosa MA, Munhoz AL, Zavaglia CA, lerardi MC: Surface finishes for Ti-6Al-4V alloy produced by direct metal laser sintering. Mater Res 2015 Aug, 18(4):838-842.

21. Wennerberg A, Albrektsson $\mathrm{T}$, Johansson $\mathrm{C}$, Andersson B Experimental study of turned and grit-blasted screw-shaped implants with special emphasis on effects of blasting material and surface topography. Biomaterials 1996, 17(1):15-22.

22. Bacchewar PB, Singhal SK, Pandey PM: Statistical modelling and - optimization of surface roughness in the selective laser sintering process. Proc Inst Mech Eng B J Eng Manuf 2007, 221:35-52.

23. Strano G, Hao L, Everson RM, Evans KE: Surface roughness analysis, modelling and prediction in selective laser melting. $J$ Mater Process Technol 2013, 213:589-597.

24. Safdar A, He HZ, Wei LY, Snis A, Chavez de Paz LE: Effect of

- $\quad$ process parameters settings and thickness on surface roughness of EBM produced Ti-6Al-4V. Rapid Prototyp J 2012 18:401-408.

25. Beard M, Ghita O, Evans KE: Using Raman spectroscopy to monitor surface finish and roughness of components manufactured by selective laser sintering. J Raman Spectrosc 2011, 42:744-748.

26. Singh R, Singh S, Singh IP: Effect of hot vapor smoothing process on surface hardness of fused deposition modeling parts. 3D Print Addit Manuf 2016 Jun 1, 3(2):128-133.

27. Kumar P, Ahuja IS, Singh R: Effect of process parameters on surface roughness of hybrid investment casting. Prog Addit Manuf 2016 Jun 1, 1(1-2):45-53.

28. Rao RV, Rai DP: Optimization of fused deposition modeling process using teaching-learning-based optimization algorithm. Eng Sci Technol Int J 2016 Mar 31, 19(1):587-603.

29. Mumtaz K, Hopkinson N: Top surface and side roughness of Inconel 625parts processed using selective laser melting. Rapid Prototyp J 2009, 15:96-103.

30. Mahamood RM, Akinlabi ET: Effect of laser power on surface finish during laser metal deposition process. In Proceedings of the world congress on engineering and computer science, vol. 2; 2014.

31. Sood AK, Ohdar RK, Mahapatra SS: Improving dimensional accuracy of fused deposition modelling processed part using 
grey Taguchi method. Mater Des 2009 Dec 31, 30(10): 4243-4252.

32. Mohd Nizam S, Shamsul Anuar S, Mohd Azman A: Effect of part features on dimensional accuracy of FDM model. ARPN J Eng Appl Sci 2016, 11(13):8067-8072.

33. Zhou JG, Herscovici D, Chen CC: Parametric process optimization to improve the accuracy of rapid prototyped stereolithography parts. Int J Mach Tools Manuf 2000 Feb 29, 40(3): 363-379.

34. Gibson I, Shi D: Material properties and fabrication parame-

•• ters in selective laser sintering process. Rapid Prototyp J 1997 Dec 1, 3(4):129-136.

35. Smith CJ, Derguti F, Nava EH, Thomas M, Tammas-Williams S, Gulizia S, Fraser D, Todd I: Dimensional accuracy of Electron Beam Melting (EBM) additive manufacture with regard to weight optimized truss structures. J Mater Process Technol 2016 Mar 31, 229:128-138.

36. Farzadi A, Solati-Hashjin M, Asadi-Eydivand M, Osman NA: Effect of layer thickness and printing orientation on mechanical properties and dimensional accuracy of 3D printed porous samples for bone tissue engineering. PloS One 2014 Sep 18, 9(9):e108252.

37. Sintering DM. Process parameter optimization for direct metal laser sintering (DMLS).

38. Mierzejewska ZA: Process optimization variables for direct metal laser sintering. Adv Mater Sci 2015 Dec 1, 15(4):38-51.

39. Niemczewska-Wójcik M, Krawczyk M, Wójcik A. The evaluation of dimensional and shape accuracy of friction pair elements: ball-cup.

40. Zarb GA, Schmitt A: The longitudinal clinical effectiveness of osseointegrated dental implants: the Toronto study. Part III: problems and complications encountered. J Prosthet Dent 1990, 64:185-194.

41. Frank MC, Joshi A, Anderson DD, Thomas TP, Rudert MJ, Tochigi Y, Brown TD: Patient-specific bone implants using subtractive rapid prototyping. bone 2010, 6:7.

42. Werner A, Lechniak Z, Skalski K, Kedzior K: Design and

- manufacture of anatomical hip joint endoprostheses using CAD/CAM systems. J Mater Process Technol 2000 Nov 22, 107(1):181-186.

43. Brown C, Lubell J, Lipman R: Additive manufacturing technical - workshop summary report. NIST; 2013 Nov. 1823. Technical Note.

44. Bertol LS, Schabbach R, dos Santos LA: Dimensional evalua-

- tion of patient-specific 3D printing using calcium phosphate cement for craniofacial bone reconstruction. J Biomaterials Appl 2017 Jan, 31(6):799-806.

45. Ogden KM, Aslan C, Ordway N, Diallo D, Tillapaugh-Fay G,

-. Soman P: Factors affecting dimensional accuracy of 3-D printed anatomical structures derived from CT data. J Digital Imaging 2015 Dec 1, 28(6):654-663.

46. Brentel AS, Vasconcellos LM, Oliveira MV, Graça ML, Vasconcellos LG, Cairo CA, Carvalho YR: Histomorphometric analysis of pure titanium implants with porous surface versus rough surface. J Appl Oral Sci 2006 Jun, 14(3):213-218.

47. de Vasconcellos LM, Cairo CA, de Vasconcellos LG, de Alen-

- castro Graça ML, do Prado RF, Carvalho YR: Porous titanium by powder metallurgy for biomedical application: characterization, cell citotoxity and in vivo tests of osseointegration. INTECH Open Access Publisher 2012.

48. Wazen RM, Lefebvre LP, Baril E, Nanci A: Initial evaluation of bone in growth into a novel porous titanium coating. J Biomed Mater Res Part B Appl Biomaterials 2010 Jul 1, 94(1):64-71.

49. Campoli G, Borleffs MS, Yavari SA, Wauthle R, Weinans H, Zadpoor AA: Mechanical properties of open-cell metallic biomaterials manufactured using additive manufacturing. Mater Des 2013 Aug 31, 49:957-965.

50. Heinl P, Müller L, Körner C, Singer RF, Müller FA: Cellular Ti$6 \mathrm{Al}-4 \mathrm{~V}$ structures with interconnected macro porosity for bone implants fabricated by selective electron beam melting Acta Biomater 2008 Sep 30, 4(5):1536-1544.

51. Bandyopadhyay A, Espana F, Balla VK, Bose S, Ohgami Y,

-• Davies NM: Influence of porosity on mechanical properties and in vivo response of Ti6Al4V implants. Acta Biomater 2010 Apr 30, 6(4):1640-1648.

52. Chawla N, Deng X: Microstructure and mechanical behavior of porous sintered steels. Mater Sci Eng A 2005 Jan 15, 390(1): 98-112.

53. Prashanth KG, Scudino S, Klauss HJ, Surreddi KB, Löber L, Wang Z, Chaubey AK, Kühn U, Eckert J: Microstructure and mechanical properties of $\mathrm{Al}-12 \mathrm{Si}$ produced by selective laser melting: effect of heat treatment. Mater Sci Eng A 2014 Jan 10, 590:153-160.

54. Brandl E, Palm F, Michailov V, Viehweger B, Leyens C: Me-

- chanical properties of additive manufactured titanium (Ti-6 $\mathrm{Al}-4 \mathrm{~V}$ ) blocks deposited by a solid-state laser and wire. Mater Des 2011 Dec 31, 32(10):4665-4675.

55. Edwards P, O'Conner A, Ramulu M: Electron beam additive manufacturing of titanium components: properties and performance. J Manuf Sci Eng 2013 Dec 1, 135(6):061016.

56. Basalah A, Esmaeili S, Toyserkani E: Mechanical properties of additive-manufactured porous titanium bio-structures with oriented macro-scale channels. Int J Adv Manuf Technol 2016 Jun 1, 84(9-12):2239-2246.

57. Agapovichev AV, Kokareva VV, Smelov VG, Sotov AV: Selective laser melting of titanium alloy: investigation of mechanical properties and smicrostructure. In IOP conference series: materials science and engineering, vol. 156, No. 1. IOP Publishing; 2016 Nov. 012031.

58. Parthasarathy J, Starly B, Raman S: A design for the additive - manufacture of functionally graded porous structures with tailored mechanical properties for biomedical applications. $J$ Manuf Process 2011 Aug 31, 13(2):160-170.

59. Wolfarth D, Ducheyne P: Effect of a change in interfacial geometry on the fatigue strength of porous-coated Ti-6Al-4V. J Biomed Mater Res Part A 1994 Apr 1, 28(4):417-425.

60. Mechanical properties of bone. University of Cambridge (available at: https://www.doitpoms.ac.uk/tlplib/bones/bone_mechanical.php).

61. Wauthle R, Vrancken B, Beynaerts B, Jorissen K, Schrooten J, Kruth JP, Van Humbeeck J: Effects of build orientation and heat treatment on the microstructure and mechanical properties of selective laser melted Ti6Al4V lattice structures. Addit Manuf 2015 Jan 31, 5:77-84.

62. Tesavibul P, Felzmann R, Gruber S, Liska R, Thompson I, Boccaccini AR, Stampfl J: Processing of $45 \mathrm{~S} 5$ Bioglass $\AA$ by lithography-based additive manufacturing. Mater Lett 2012 May 1, 74:81-84.

63. Tolosa I, Garciandía F, Zubiri F, Zapirain F, Esnaola A: Study of mechanical properties of AISI 316 stainless steel processed by "selective laser melting", following different manufacturing strategies. Int J Adv Manuf Technol 2010 Nov 1, 51(5-8):639-647.

64. Chan KS, Koike M, Mason RL, Okabe T: Fatigue life of titanium alloys fabricated by additive layer manufacturing techniques for dental implants. Metall Mater Trans A 2013 Feb 1, 44(2): $1010-1022$

65. Facchini L, Magalini E, Robotti P, Molinari A: Microstructure and mechanical properties of Ti-6Al-4V produced by electron beam melting of pre-alloyed powders. Rapid Prototyp J 2009 May 29, 15(3):171-178.

66. Trosch T, Strößner J, Völkl R, Glatzel U: Microstructure and -. mechanical properties of selective laser melted Inconel 718 compared to forging and casting. Mater Lett 2016 Feb 1, 164 $428-431$.

67. Frazier WE: Metal additive manufacturing: a review. J Mater Eng Perform 2014 Jun 1, 23(6):1917-1928.

68. Yadroitsev I, Thivillon L, Bertrand P, Smurov I: Strategy of manufacturing components with designed internal structure 
by selective laser melting of metallic powder. Appl Surf Sci 2007 Dec 15, 254(4):980-983.

69. Mower TM, Long MJ: Mechanical behavior of additive manufactured, powder-bed laser-fused materials. Mater Sci Eng A 2016 Jan 10, 651:198-213.

70. Novaes Jr AB, Souza SL, Barros RR, Pereira KK, lezzi G, Piattelli A: Influence of implant surfaces on osseointegration. Braz Dent J 2010, 21(6):471-481.

71. Shibli JA, Mangano C, Mangano F, Rodrigues JA, Cassoni A, Bechara K, Ferreia JD, Dottore AM, Iezzi G, Piattelli A: Bone-toimplant contact around immediately loaded direct laser metal-forming transitional implants in human posterior maxilla. J Periodontol 2013 Jun, 84(6):732-737.

72. Witek L, Marin C, Granato R, Bonfante EA, Campos F, Bisinotto J Suzuki M, Coelho PGCharacterization and in vivo evaluation of laser sintered dental endosseous implants in dogs: J Biomed Mater Res Part B Appl Biomaterials 2012 Aug 1, 100(6):1566-1573.

73. Stübinger S, Mosch I, Robotti P, Sidler M, Klein K, Ferguson SJ,

- Rechenberg B: Histological and biomechanical analysis of porous additive manufactured implants made by direct metal laser sintering: a pilot study in sheep. J Biomed Mater Res Part B Appl Biomaterials 2013 Oct 1, 101(7):1154-1163.

74. Bowers M, Yoo D, Marin C, Gil L, Shabaka N, Goldstein M, Janal M, Tovar N, Hirata R, Bonfante E, Coelho P: Surface characterization and in vivo evaluation of laser sintered and machined implants followed by resorbable-blasting media process: a study in sheep. Med Oral Patol Oral Cirugia Bucal 2016 Mar, 21(2):e206.

75. Shah FA, Snis A, Matic A, Thomsen P, Palmquist A: 3D prin-

- ted Ti6Al4V implant surface promotes bone maturation and retains a higher density of less aged osteocytes at the bone implant interface. Acta biomater 2016 Jan 15, 30: 357-367.

76. Shah FA, Omar O, Suska F, Snis A, Matic A, Emanuelsson L,

- $\quad$ Norlindh B, Lausmaa J, Thomsen P, Palmquist A: Long-term osseointegration of 3D printed CoCr constructs with an interconnected open-pore architecture prepared by electron beam melting. Acta biomater 2016 May 31, 36:296-309.

77. Chen $\mathrm{CH}$, Liu JM, Chua CK, Chou SM, Shyu VB, Chen JP: Cartilage tissue engineering with silk fibroin scaffolds fabricated by indirect additive manufacturing technology. Materials 2014 Mar 13, 7(3):2104-2119.

78. Soboyejo WO, Srivatsan TS: Advanced structural materials: properties, design optimization, and applications. CRC Press; 2006:359-400.

79. Trelewicz JR, Halada GP, Donaldson OK, Manogharan G: Microstructure and corrosion resistance of laser additively manufactured 316L stainless steel. JOM 2016, 68:850-859. 